Ilmu Pertanian (Agricultural Science)

Vol. 2 No. 3 December, $2017: 144-153$

Available online at http://journal.ugm.ac.id/jip

DOI: doi.org/10.22146/ipas.33085

\title{
Genetic Diversity Of Local Maize Germplasm Of Tana Toraja South Sulawesi Using SSR (Simple Sequence Repeat) Markers
}

\author{
Ramlah $^{1 *}$, Isna Rasdianah Aziz², Cut Muthiadin², Mashuri Masri², Muhammad Khalifah \\ Mustami², Marcia Bunga Pabendon $^{3}$ \\ ${ }^{1}$ Department of Biology Faculty of Biology, Gadjah Mada University \\ Jl. Teknika Selatan, Sekip Utara, Bulaksumur, Yogyakarta 55281, Indonesia \\ ${ }^{2}$ Department of Biology Faculty of Science and Technology, UIN Alauddin Makassar \\ J1. H. M.Yasin Limpo No. 36 Samata, Gowa, South Sulawesi, Indonesia \\ ${ }^{3}$ Cereals Plant Research Institute, Agricultural Research and Development Agency \\ Jl. Dr. Ratulangi 274 Maros Sulawesi Selatan, Indonesia \\ *Corresponding email: ramlahganis@gmail.com
}

Received:06 ${ }^{\text {th }}$ February 2018; Revised: $1^{\text {st }}$ May 2018; Accepted: 05 $5^{\text {th }}$ May 2018

\begin{abstract}
Plant genetic diversity is an emerging variation in a crop group caused by its genetic factors. Local corn germplasm as a source of plant genes that are able to adapt to the local environment. The purpose of this research is to obtain information on genetic variation of Tana Toraja local maize germ plasm using SSR (Simple Sequence Repeat) marker. This research was conducted at Balitsereal Molecular Biology Laboratory, Agricultural Research Agency in Maros Regency, South Sulawesi. A total of 4 local maize populations were analyzed by laboratory experimental method with observation with NTSYS pc 2.1 program. The results showed that the average number of alleles was 3.72 alleles per locus and the polymorphism rate of 0.53 with the genetic similarity coefficient was in the range of 0.47 to 0.85 .2 main clusters formed in the genetic similarity coefficient 0.47 . Klaster I is Local Dalle Pondan and Local Purple. Klaster II is Local Bebo and Kandora. The genetic distance is in the range of 0.15 to 0.74 with an average genetic distance of 0.46. From the data obtained shows that the 4th germplasm of the population of Tana Toraja Local maize diteleti has a very informative level of genetic diversity. Genetic diversity of local maize germplasm of Tana Toraja, can be used as a source of genes in the assembly of improved varieties in the future.
\end{abstract}

Keywords: Bebo, Dallepondan, Genetic Diversity, Germplasm, Kandora, Local Maize Tana Toraja, Purple, SSR.

\section{INTRODUCTION}

The diversity of regions in Indonesia creates a variety of areas that can be seen with the variation of regional character, topography, soil, water availability and climate. This diversity has established plants to grow and adapt to specific locations. Cultivars of plants that have a good tolerance in local conditions known as Local germplasm (landrace). In general, Local germplasm is generally less productive than commercial cultivars, but germplasm is extremely important in detecting genes or specific traits for tolerance or resistance to biotic and abiotic factors in nature (Araujo and Nass, 2002). The occurrence of genetic erosion and human-caused habitat damage has increased the important role of germ plasm (Carvalho et al., 2004). The germ plasm of maize has a high potential to adapt to certain environmental conditions, a source of genetic variation that will be needed in the future (Paterniani et al. 2000).

Farmers have cultivated maize and made their selection in a narrow area. Gradually emerging genotypes Local white seed, yellow, white and yellow mixture, mature early, pest resistant and able to adapt well in their respective areas (Baihaki, 2004). The high genetic diversity in the population is very useful, especially in the assembling of hybrid varieties with high yield potential (Hoxha et al., 2004).

Juhriah et al. (2012), confirmed that the collection of germplasm of maize in Balitsereal continues to increase the number of its access through exploration activities both in production centers, isolated areas, endemic areas and others. The germplasm material 
is only issued when it is reproduced or rejuvinated, has not been used, or characterized to obtain important characters. The conservation of germplasm in gene banks is an effective way to maintain germplasm plants that can be used by future generations and for future plant breeding.

In South Sulawesi maize has a varied Local population. Some of them are from Tana Toraja area. The results of screening of resistance to bulai diseases indicate that Local Bebo and Local Kandora are somewhat resistant to stabbing diseases (Muis et al., 2015), while Local Purple and Local Dalle Pondan are favored by farmers, so it is always planted every growing season of maize. These four populations are important germplasm that can serve as an important source of genes in the assembling of superior varieties. Given the government's recommendation to plant the recommended superior varieties such as hybrids, the important germplasm can become extinct. Therefore, there is a need to maintain the population. Based on the above, it is necessary to characterize, as the basis for protecting the important germplasm.

In addition to morphological characterization, important molecular characterization is performed because it is not influenced by the environment so the data produced is more accurate (Molin et al., 2013). One of the most widely used molecular markers in estimating genetic relationships, analysis of genetic diversity levels and has been widely used in corn crops is the Simple Sequence Repeats (SSR) (Adeyemo et al. 2011, Terra et al., 2011, Liu et al., 2003, Senior et al., 1998). SSR is a marker based on polymerase chain reaction (Polymerase Chain Reaction PCR) using nucleotide sequences as primers (Gupta et al. 1996), DNA sequences containing short, repetitive (1-6 nucleotide) tandem repetitive motifs throughout the genome codominant, more specific and has a high degree of polymorphism (Filippi et al., 2015, Prasanna, 2010, Vigouroux et al., 2002, Akkaya et al., 1992). The use of SSR markers has high reproducibility and accuracy, so it is expected to be able to explore genetic diversity of Tana Toraja Local Maize maize germplasm. Hoxha et al. (2004), reported that genetic diversity from 20 Albanian Local maize populations using 20 SSR primers showed an average number of alleles of 9.1 alleles per SSR locus, with an average polymorphism (PIC) value of 0.71 . The results of molecular analysis show a genetic variation of $59 \%$ in the population and $41 \%$ between populations. The purpose of this research is to know the level of genetic diversity 4 population of germplasm of maize Local Tana Toraja using SSR marker.

\section{MATERIALS AND METHODS}

\section{Plant Material and DNA Extraction}

The research was conducted at the Laboratory of Molecular Biology and Greenhouse, Cereals Research Institute (Balitsereal), in Maros. Plant material used consisted of 4 Local populations derived from Tana Toraja area of South Sulawesi, where each population consists of 25 individuals. In contrast to inbred homozygous genetic conditions for one character by combining 10-15 individual plants into one. However, for the population because of its heterozygous genetic conditions so that each individual has a different character, it takes 15-25 individuals per population who are considered to have represented the characters in the genome of that one population.

All local Maize genotypes were grown on polybags $(15 \times 20 \mathrm{~cm})$ containing a mixture of compost and soil (1:1) every polybag was grown by 20 individuals. Plants are kept in greenhouses and watered daily according to planting conditions. Plants used for DNA extraction are 10-15 days after planting. Part of the plant taken is a young leaf that has been opened perfectly, cut into small pieces, then weighed $0.4 \mathrm{~g} / \mathrm{sample}$. The process of extraction, electrophoresis and visualization of DNA follows the procedure of George et al. (2004) and Khan et al. (2004). The quantity and quality of DNA extracts were measured by $\lambda$ DNA standards through a horizontal electrophoresis process using $1 \%$ agarose gel.

\section{Primer and PCR Amplification}

Each plant DNA sample was analyzed using the Pelicular Chain Reaction (PCR) PTC-200 Peltier Thermal Cycler machine using 30 Primer (Forward and Reverse) SSR cornspreading on 10 corn chromosomes. Total reaction for PCR analysis was $10 \mu \mathrm{l}$, consisting of $1 \mu \mathrm{l}$ of Maize DNA, $1 \mu \mathrm{l}$ of primary (forward and reverse), PCR buffer $1 \mathrm{X}$ (10 Mm Tris $\mathrm{HCl} \mathrm{pH}-8,50 \mathrm{Mm} \mathrm{KCl}, 0.01 \%$ gelatin, $1.5 \mathrm{Mm}$ $\mathrm{MgCl}_{2}, 0.125 \mathrm{dNTP}$ and 1 unit of DNA Taq polymerase The amplification process is 30 cycles, consisting of the initial denaturation at $94^{\circ} \mathrm{C}$ for $5 \mathrm{~min}$, denaturation at $94^{\circ} \mathrm{C}$ for 45 seconds, annealing at $52-60^{\circ} \mathrm{C}$ (corresponding to Melting Temperature (Tm) oC primer) for 1 minute, extension at $72^{\circ} \mathrm{C}$ for 1 minute, then cycle cycling back to step II, 29 times, final extension at $72^{\circ} \mathrm{C}$ for 5 minutes and final hold $4^{\circ} \mathrm{C} \alpha$.

The amplification results were then separated using a mini vertical electrophoresis machine (Dual 
Mini-Verticals Complete System MGV-202-33 CBG Scientific Co.) using an $8 \%$ non-denaturation polyacrylamide gel in $1 \mathrm{X}$ buffer TBE, $1 \mathrm{~g} / 1$ marker and $20 \mathrm{~g} \mathrm{NaOH}$ solution. 1 added formaldehyde 1000 $\mu l$. The results are visualized on a white glass table to be seen clearly, next to the marker given a small ruler to make it easier to read the size of the tape on the photo.

\section{Data analysis}

The result of visualization of DNA disk banding pattern by way of alleles is calculated molecular weight based on the position of the DNA band fragments against known DNA markers/markers. The disk data is in binary data form, if no tape is written zero (0), if there is one written band (1) and the ribbons are blurred and too difficult for diskoring to be marked missing data with number nine (9). The results of scoring data, then selected based on the number of missing data generated.

Level polymorphism or Polymorphic Information Content (PIC) based on terminology, PIC value is equal to the value of gene diversity (heterozygosity). The PIC value provides an estimate of the distinguishing power of the marker by counting not only the number of alleles in one locus, but also the relative frequency of the alleles of an identified population. A markup focus with a large number of alleles will be present at a frequency equal to the highest PIC value. The PIC values were calculated for each SSR marker (Smith et al. 1997). The value of PIC is used in measuring the diversity of alleles at one locus by the formula:

$$
P I C=1-\sum_{i}^{n} \quad f_{1}^{2} i=1,2,3 \ldots \ldots . n
$$

Information: PIC = Polymorphic Information Content (polymorphism level); $\mathrm{f}_{1}{ }^{2}=$ Frequency of allele to-i.

The analysis of the genetic distance matrix is an analysis that compares the character's inequality to the total number of characters. The genetic distance matrix can be obtained from the results of genetic similarity analysis with the formula:

$$
\mathrm{S}=1-\mathrm{GS}
$$

Information: $\mathrm{S}=$ Genetic Distance; $\mathrm{GS}=$ Genetic Similarity.

The degree of genetic similarity is the level of character similarity, in this case the collected ribbon fragments of the identified genotypes. The genetic similarity (GS) level is estimated from the number of allele data using the Jaccard coefficient (Rohlf,
2000) with the formula:

$$
\mathrm{GS}=\frac{m}{(n+u)}
$$

Information: $\mathrm{m}=$ the number of DNA (allele) bands of the same position; $\mathrm{n}=$ total DNA band; $\mathrm{u}=$ the number of bands (alleles) of DNA that are not equal in position.

\section{RESULT AND DISCUSSION}

\section{PCR Amplification}

Visualization of DNA band pattern of PCR amplification result using 30 SSR primers showed that there were 5 primers and 4 individuals who experienced poorly ampilifikasi indicated by the number of missing data. Pabendon et al. (2007), said that individual corn that produces missing data $>15 \%$ level is issued, because it will affect the validity of the data generated. As for the things that need to be considered in selecting primers that will be used for analysis of genetic diversity of corn such that the ribbon produced is easy to read, the state of the tape is clear, and produce polymorphic band fragments. The 5 primers which can not be used for further analysis are phi299852, phi374118, phi1153, phi420701, and phi452693 and 4 individuals namely Local Kandora-19, Local Purple-19 and 21, and Local Dalle Pondan-17. One of the SSR amplified primary PCR primers using the phi328175 primer is shown in Figure 1. The image shows the presence of thick DNA band patterns and there are missing data in the Bebo 21, and 22 local samples, Local Kandora 10, 18 and 20, Local Purple 21 and Local Dalle Pondan 23. In sample number 16, the DNA bands formed are very smooth and thin. There are 5 alleles detected on primer phi328175 at $151 \mathrm{bp}, 140 \mathrm{bp}, 123.5 \mathrm{bp}, 118 \mathrm{bp}$, and $92.8 \mathrm{bp}$.

\section{SSR Marking Data Profiles}

The data profile of SSR 25 marks can be seen in Table 1. The used SSR spans spread relatively evenly on 10 corn chromosomes ie 2 loci on chromosome 1, 3 locus on chromosome 2,1 locus on chromosome 3,3 locus on chromosome 4, 3 locus at chromosomes 5, 2 loci on chromosome 6, 2 loci on chromosome 7, 2 loci on chromosome 8,4 loci on chromosome 9 and 3 locus on chromosome 10.

Based on the SSR mark profile, it was found that the polymorphism level (PIC) ranged from 0.11 (phi097) -0.80 (phi041), averaging 0.53. Polymorphism is the variation of alleles in certain DNA loci from a population. Botstein et al. (1980), stated that PIC values can be standardized for evaluating genetic markers based on DNA bands of PCR amplification 
$\begin{array}{lllllllllllllllllllllllllll}M & 1 & 2 & 3 & 4 & 5 & 6 & 7 & 8 & 9 & 10 & 11 & 12 & 13 & 14 & 15 & 16 & 17 & 18 & 19 & 20 & 21 & 22 & 23 & 24 & 25 & M\end{array}$

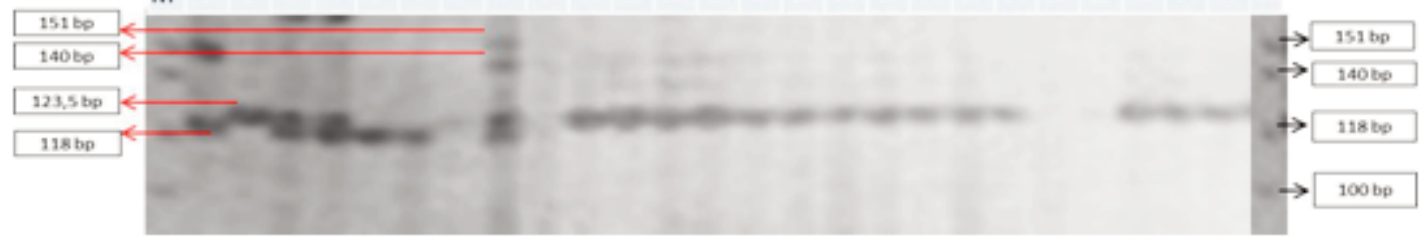

Local Bebo

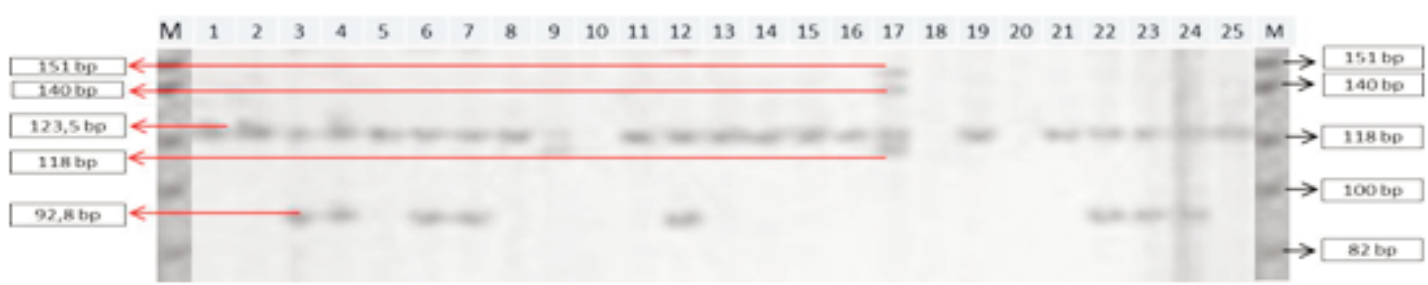

Local Kandora
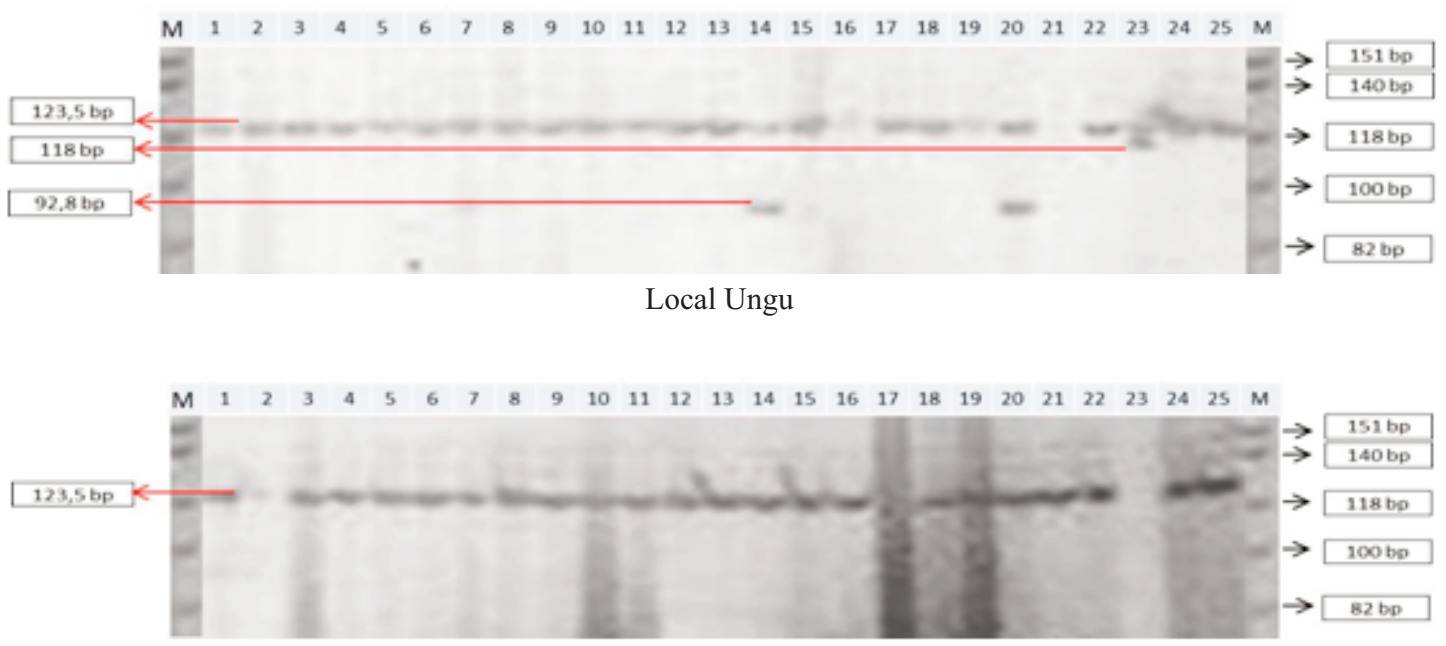

Local Dalle Pondan

Figure 1. Visualization of banding pattern DNA four population of maize Local result of PCR using primer phi328175.

results. The PIC value is classified into 3 classes: PIC $>0.5=$ very informative, PIC between $0.25-0.5$ $=$ medium, and PIC $<0.25=$ low. The higher the PIC value, the more detected the allele. The high average PIC values indicate the high diversity of genetic material under study. The lowest PIC value in the primary SSR of corn phi097 is 0.11 and the highest PIC value at phi041 primer is 0.8 . That is, that the SSR phi041 marker located on chromosome 10 , has a high ability in identifying the cultivars of the Tana Toraja Local crop genetically. Based on the average value of PIC generated 0.53 , this indicates that the level of PIC produced in this study is quite informative. Anderson et al. (1993), reveals that the greater the PIC value of a primer, the better the primer is used as a molecular marker primarily to know genetic diversity. Johari et al. (2008), says that polymorphism is an expression of genes and can be detected by electrophoresis techniques, which are subsequently scored, whether or not DNA bands show genetic variation in the population.
The total number of alleles obtained is 93 alleles with an average amount of 3.72 with an allele range between 2-7 alleles per locus. The lowest number of alleles on primer phi053, phi423796, phi032, and phi448880 is only 2 alleles, whereas the largest number of alleles in the primary umc1279 produced as many as 7 different alleles.

The SSR focus analyzed has an allele size or base-pair size between 71.33 - 500 bp. The lowest allele size is on primer umc 1143 which is $71.33 \mathrm{bp}$ and highest at phi96100 primer is 500 bp.Utami et al. (2013), states that the larger the molecular size, the lower the rate of migration.

\section{Dendrogram Construction}

A cluster analysis of 4 local maize populations classified according to the matrix of genetic similarity. The dendogram construction results show that the genetic similarity coefficient ranges from 0.47 to 0.85 (Figure 2).Vika et al. (2015), states that the genetic similarity coefficient ranges from 0 to 1 . If the genetic similarity 
Table 1. Profile data 25 SSR corn marker

\begin{tabular}{|c|c|c|c|c|c|c|}
\hline No. & Primer & Bin no. & $\begin{array}{l}\text { Polymorphism } \\
\text { (PIC) }\end{array}$ & $\begin{array}{l}\text { Number of } \\
\text { alleles }\end{array}$ & Allele size (bp) & $\begin{array}{c}\text { Melting } \\
\text { Temperatur }(\mathrm{Tm}) \mathrm{OC}\end{array}$ \\
\hline 1 & phi097 & 1.01 & 0.11 & 3 & $86.00-89.20$ & 60 \\
\hline 2 & phi227562 & 1.12 & 0.57 & 4 & $26.67-369.00$ & 54 \\
\hline 3 & phi96100 & 2.00 & 0.6 & 5 & $264.50-500.00$ & 54 \\
\hline 4 & phi083 & 2.04 & 0.39 & 3 & $123.50-129.00$ & 52 \\
\hline 5 & phi101049 & 2.09 & 0.55 & 5 & $212.25-280.00$ & 54 \\
\hline 6 & phi053 & 3.05 & 0.56 & 2 & $160.80-175.50$ & 56 \\
\hline 7 & phi072 & 4.00 & 0.35 & 4 & $140.00-232.67$ & 52 \\
\hline 8 & phi079 & 4.05 & 0.74 & 4 & $158.00-167.33$ & 60 \\
\hline 9 & phi093 & 4.08 & 0.57 & 4 & $266.71-349.67$ & 60 \\
\hline 10 & nc130 & 5.00 & 0.76 & 3 & $129.00-180.40$ & 54 \\
\hline 11 & phi109188 & 5.00 & 0.59 & 4 & $158.53-230.63$ & 54 \\
\hline 12 & phi331888 & 5.04 & 0.71 & 3 & $125.33-131.75$ & 58 \\
\hline 13 & umc1143 & $6.00-6.01$ & 0.50 & 3 & $71.33-86.50$ & 54 \\
\hline 14 & phi423796 & 6.01 & 0.33 & 2 & $120.75-133.71$ & 54 \\
\hline 15 & phi034 & 7.02 & 0.60 & 4 & $118.00-175.50$ & 56 \\
\hline 16 & phi328175 & 7.04 & 0.34 & 5 & $92.80-151.00$ & 54 \\
\hline 17 & umc1304 & 8.02 & 0.17 & 3 & $123.50-151.00$ & 54 \\
\hline 18 & phi080 & 8.08-8.09 & 0.63 & 5 & $140.00-175.50$ & 54 \\
\hline 19 & umc1279 & 9.00 & 0.59 & 7 & $85.00-170.60$ & 54 \\
\hline 20 & phi065 & 9.03 & 0.70 & 4 & $224.50-427.00$ & 54 \\
\hline 21 & phi032 & 9.04 & 0.38 & 2 & $175.50-200.00$ & 56 \\
\hline 22 & phi448880 & 9.05 & 0.54 & 2 & $157.13-179.00$ & 54 \\
\hline 23 & phi041 & 10.00 & 0.80 & 3 & $151.00-163.25$ & 56 \\
\hline 24 & phi96342 & 10.02 & 0.47 & 4 & $181.63-224.50$ & 54 \\
\hline 25 & umc1196 & 10.07 & 0.70 & 5 & $219.60-360.71$ & 54 \\
\hline Total & & - & 13.25 & 93 & $71.33-500$ & \\
\hline \multicolumn{2}{|c|}{ Average } & - & 0.53 & 4 & & \\
\hline
\end{tabular}

value close to 0 is low, and if the genetic similarity value is close to 1 , it is said to be high. In the genetic similarity coefficient 0.48 to 4 local maize population were analyzed to produce 4 clusters. Cluster I consists of local Ungu population (20 individuals) and local population Dalle-Pondan (23 individuals). Klaster II consists of Local Kandora (4 individuals), Local Purple (3 individuals) and Local Dalle-Pondan (1 individual). Cluster III consists of Local Bebo (7 individuals), and cluster IV consists of Local Bebo (18 individuals) and Local Kandora (20 individuals).

This data shows that each cluster is filled by more than one population, except in cluster III, filled only by the local population Bebo. This indicates that there are dominant characters or genes that cause different populations to be in the same cluster. Leachate can be seen in Table 2.

Table 3 shows the percentage of 4 local maize popu- lation populations in 4 clusters that are formed. The highest percentage of Local corn Bebo $(72 \%)$ and Local Kandora (83.3\%) in the fourth cluster, and Local Purple (87\%) and Local Dalle-Pondan (95.8\%) in the I-cluster. These data indicate that all 4 Local Maize populations analyzed are grouped by function. As it is known that the local population of Bebo and Local Kandora belong to the nomal corn that is widely used for animal feed. While the local population of Purple and Local Dalle-Pondanbelong to the specific corn, which is the type of maize that contains special functional characters. For example in Purple corn has anthocyanin content that serves as an antioxidant. Local Dalle-Pondan seeds are cloudy white, indicate a high enough starch content (pulut), and has a slightly shrunken seed, indicating a sufficient sugar content at the time of physiological maturity. The second cluster consists of only 8 individuals (Table 3 ) consisting of 3 different Local 
Table 2. Number of individuals from each population in each cluster

\begin{tabular}{lccccc}
\hline \multirow{2}{*}{ Local genotype } & \multicolumn{3}{c}{ Clusters } & \multirow{2}{*}{ Total } \\
\cline { 2 - 5 } & I & II & III & IV & \\
\hline Local Bebo & 0 & 0 & 7 & 18 & 25 \\
Local Kandora & 0 & 4 & 0 & 20 & 24 \\
Local Ungu & 20 & 3 & 0 & 0 & 23 \\
Local Dalle-Pondan & 23 & 1 & 0 & 0 & 24 \\
\hline Total & 43 & 8 & 7 & 38 & 96 \\
\hline
\end{tabular}

Table 3. Percentage of local genotype distribution in each cluster

\begin{tabular}{lcccc}
\hline \multirow{2}{*}{ Local genotype } & \multicolumn{4}{c}{ Clusters } \\
\cline { 2 - 5 } & I (\%) & II $(\%)$ & III (\%) & IV (\%) \\
\hline Local Bebo & 0.0 & 0.0 & 28.0 & 72.0 \\
Local Kandora & 0.0 & 16.7 & 0.0 & 83.3 \\
Local Ungu & 87.0 & 13.0 & 0.0 & 0.0 \\
Local Dalle-Pondan & 95.8 & 4.2 & 0.0 & 0.0 \\
\hline
\end{tabular}

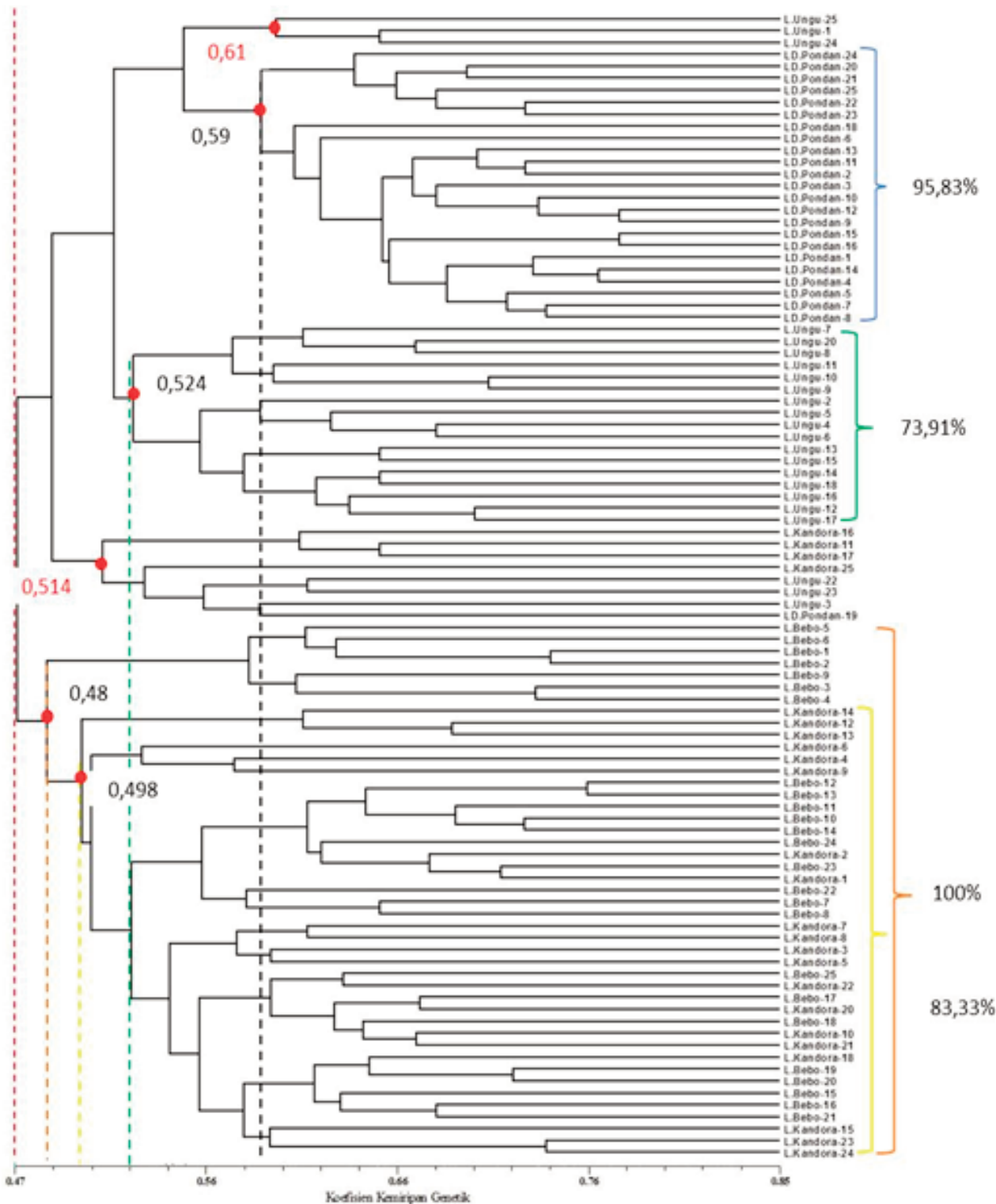

Figure 2. Dendrogram Construction Results four Tana Toraja Local Corn Population (Bebo, Kandora, Purple and DallePondan) based on 25 primary polymorphic SSR information using NTSYS pc 2.1 program 
populations namely Local Kandora, Local Purple, and Local Dalle-Pondan, indicating a high variation. While in the third cluster only consists of 7 individuals who are dominated by the local population Bebo, showed a low variation compared to the other three clusters.

The 4 local maize populations, DallePondan is dominant in the genetic similarity coefficient of 0.59 of $95.83 \%$. Purple is dominant in the genetic similarity coefficient 0.524 of $73.91 \%$. Kandora on genetic similarity coefficient 0.498 equal to $83.34 \%$. Bebo on the genetic similarity coefficient of 0.48 for $100 \%$. Several other individuals from DallePondan, Kandora and Purple spread on genetic similarity coeffects of 0.61 and 0.514 .

The presence of individuals within the dominant population occupying the same cluster can be due to the high degree of individual interaction within the population, so that the characters/genes produced will not be much different from the parent, it also shows that individuals in the population are still are close enough. It also shows that the character/nucleotide structure of DNA possessed by individuals in this population is almost identical. As is known that the Local Delle-Pondan and Purple Local classified special corn, meaning there are special characters owned and not owned by normal corn. Meanwhile, Local Kandora and Local Bebo classified as normal maize. High genetic diversity is necessary to maintain the life of a species from pest attack, reproductive trait and adaptation to environmental conditions. Nurtjahjaningsih et al. (2014), states that factors that may affect the magnitude of the genetic diversity of a plant, such as the nature of reproduction and its habitat in nature. The existence of DNA nucleotide changes leads to genetic diversity, this change can affect individual reactions to a particular environment or phenotype of organisms that can be seen by the naked eye

Grouping the 4 Local populations using NTSYS pc 2.1 program. can be seen in Figure 2.

The grouping is based on the presence of genotypes that occupy the same branching. The coefficient of correlation kofenetik ( $r$ ) is still very varied that is $0.3-89.0 \%$. This may be because the number of primers used is still lacking, the plant material studied is a population so it is very likely to contain many gene variations. Thus, to increase the confidence level of the grouping, the number of primers used plus 50 primers (CIMMYT recommendation). Rohlf (2000), states that the more polymorphic primers used the greater the value of $r$.

\section{Genetic Distance}

The genetic distance of the 4 populations ranged from 0.15 to 0.74 with an overall genetic distance of 0.46 . The lowest genetic distance is 0.15 in the individual DP-14 vs. DP- 1 and the highest genetic distance is 0.74 in the individual DP-12 vs. K-1. Based on Local population type, the lowest average genetic distance is Local Dalle Pondan (0.35), whereas the 3 other Local population have same average genetic distance that is Purple Local (0.43), Local Kandora (0.44), and Local Bebo (0.42). That is, the genetic similarity level of Dalle-Pondan Local population, higher than other populations. This type of maize is routinely planted every growing season of corn, as demand for consumption is high enough among the Tana Toraja community. Thus, farmers always do morphological selection phenotypically as they wish. Thus, the resulting morphological uniformity is higher, especially in seed appearance.

Based on the number of clusters formed, the lowest average genetic distance is in cluster III ( 0.38$)$ dominated by Local Bebo, and the highest average genetic distance in cluster II (0.46). The local population of Bebo in cluster III can be used as a source of genetic material resistant to sour, because it is not mixed with other populations. In general, the genetic diversity data of 4 Localized dianalis populations resulted in highly informative data, indicated by a PIC level of 0.53 with a moderately classified genetic diversity level represented by the average number of alleles of 4 alleles per SSR locus as well as having coefficient values genetic diversity ranges from 0.47 to

Table 4. Genetic Distance 4 Local Maize Population

\begin{tabular}{|c|c|c|c|c|c|c|c|}
\hline \multirow{2}{*}{ Local genotype } & \multirow{2}{*}{$\begin{array}{c}\text { GD. } \\
\text { Lowest }\end{array}$} & \multirow{2}{*}{$\begin{array}{c}\text { GD. } \\
\text { Highest }\end{array}$} & \multirow{2}{*}{$\begin{array}{l}\text { GD. Average } \\
\text { In Population }\end{array}$} & \multicolumn{4}{|c|}{ GD. Average in Clusters } \\
\hline & & & & $\mathrm{C}_{1}$ & $\mathrm{C}_{2}$ & $\mathrm{C}_{3}$ & $\mathrm{C}_{4}$ \\
\hline Local Bebo & 0.21 & 0.61 & 0.42 & & & & \\
\hline Local Kandora & 0.19 & 0.69 & 0.44 & & & & \\
\hline Local Ungu & 0.17 & 0.63 & 0.43 & 0.42 & 0.46 & 0.38 & 0.43 \\
\hline Local Dalle-Pondan & 0.15 & 0.58 & 0.35 & & & & \\
\hline Population mix & 0.15 & 0.74 & 0.46 & & & & \\
\hline \multicolumn{8}{|l|}{ GD : Genetic Distance } \\
\hline $\mathrm{C}:$ Clusters & & & & & & & \\
\hline
\end{tabular}


0.85 . This data also shows that not too many other types of maize such as the type of hybrid developed in Tana Toraja. As is known to bring the needs of corn based fodder, generally purchased from outside the region

The result of accumulation of genetic distance (Genetic dictance) from the 4 population can be seen in Table 4.

\section{SSR Marking Data Profiles}

Based on the above, the average general value is greater than the average per population. Pabendon et al. (2007), stated that if the average value of genetic distance in the cluster is smaller than the general average then crossovers within clusters should be avoided. Conversely, if the average value of genetic distance in the cluster is greater than the general average, then the intersection of inbreds in the same cluster can be done.

The close proximity of genetic distance generated by individuals in the population can be affected by the presence of natural gene mixing, due to the process of gene flow between populations through the distribution of pollen and through seed. Another factor that can also affect the amount of population distribution. Large population distribution, can increase crop diversity, but can eliminate the unique gene properties of a population. Tasma et al. (2003) revealed that corn individuals with high levels of genetic diversity are potential for use in breeding programs in order to produce progeny indicating high levels of heterosis.

Individuals who have genetic proximity, allegedly come from elders who are closely related. In contrast, individuals with relatively high genetic distances, allegedly from elderly relatives closely related to other elders. The above results, can be used as the determination of the parent for making superior seeds. The further the relationship of kinship between individuals, the smaller the success of the cross, but the possibility to obtain a superior individual is greater if the cross is successful. Marriage between individuals with close genetic distance or kinship relationship has the same effect of increasing homozygosity, whereas marriage between individuals of large genetic distances or kinship has a far-reaching effect of heterozicity (Rahmawati et al., 2009). The closer kinship is indicated by smaller genetic distance values (large matrix coefficients). So the higher the genetic distance, the lower the level of genetic similarity between accessions (Dewi et al., 2013).

\section{CONCLUSIONS}

Genetic diversity analysis 4 Tana Toraja Local
Corn population using SSR marker, the results showed that the average number of alleles was 3.72 alleles per locus and the polymorphism rate of 0.53 with the genetic similarity coefficient was in the range of 0.47 to 0.85 . There are two main clusters formed in the genetic similarity coefficient 0.47 . Klaster I is Local DallePondan and Local Purple. Klaster II is Local Bebo and Kandora. The genetic distance is in the range of 0.15 to 0.74 with an average genetic distance of 0.46 . From the data obtained shows that the 4 th germplasm of the population of Tana Toraja Local maize diteleti has a very informative level of genetic diversity. The results showed that the average number of alleles was 3.72 alleles per locus and the polymorphism rate of 0.53 with the genetic similarity coefficient was in the range of 0.47 to 0.85. 2 main clusters formed in the genetic similarity coefficient 0.47. Klaster I is Local DallePondan and Local Purple. Klaster II is Local Bebo and Kandora. The genetic distance is in the range of 0.15 to 0.74 with an average genetic distance of 0.46 . From the data obtained shows that the 4 th germplasm of the population of Tana Toraja Local maize investigated has a very informative level of genetic diversity.

\section{REFERENCES}

Adeyemo, O., A. Menkir, G. Melaku, and Omidji. 2011. Genetic diversity assessment and relationship among tropical yellow endosperm maize inbred lines using SSR markers. Maydica. 56:1703-1709.

Afonso, A.V. 2013. Genetic diversity of local maize (Zea mays L.) germplasm from eight agro-ecological zones in Mozambique. Master thesis in Biology. Thesis. Department of Plant Breeding. Swedish University of Agricultural Science. Alnarp.

Akayya, M.S., A.A. Bhagwat, and P.B. Cregan. 1992. Length polymorphisms of simple sequence repeat DNA in soybean. Genetics. 132:11311139.

Anderson, J.A, G.A. Churchill, J.E. Autrique, S.D. Tanksley, and M.E. Sorrels. 1993. Optimizing parental selection for genetic linkage maps. Jurnal Genome. 36: 181-186.

Araujo, P.M. and L.L. Nass. 2002. Caracterizacao a avaliacao de populacoes de milho crioulo. Sci. Agric. 59:589-593.

Asy'ari, M. dan A.S. Noer. Optimasi konsentrasi $\mathrm{MgCl} 2$ dan suhu annealing pada proses amplifikasi multifragmens mtDNA dengan metode PCR. Artikel:JKSA. 8(1):24-28. 
Baihaki, A. 2004. Mengantisipasi persaingan dalam menuju swasembada varietas unggul. Prosiding Simposium PERIPI. Bogor, 5-7 Agustus 2004. Hlm:36-49.

Carvalho, V.P., C.V. Ruas, J.M. Ferreira, R.M.P. Moreira, and P.M. Ruas. 2004. Genetic diversity among maize (Zea mays L.) landraces assessed by RAPD markers. Genetics and Molecular Biology. 27(2):228-236.

CIMMYT (International Maize and Wheat Improvement Center). 2004. Protokol untuk karakterisasi jagung secara genotipik menggunakan marka SSR serta analisis data. Asian Maize Biotechnology Network.

Dewi, I.S., Y. Arisanti, S. Bambang, Purwoko, Hariyadi, M. Syukur. 2013. Keragaman genetik beberapa genotipe jarak pagar (Jatropha curcas 1.) Berdaya hasil tinggi berdasarkan karakter morfologi, agronomi, dan isozim. Jurnal AgroBiogen. 9(1):28-38.

Filippi, C.V., N. Aguirre, J.G. Rivas, J. Zubrzycki, A. Puebla, D.Cordes, M.V. Moreno, C.M. Fusari, D. Alfarez, R.A. Heinz, H.E. Hopp, N.B. Paniego, and V.V. Lia. 2015. Population structure and genetic diversity characterization of a sunflower association mapping population using SSR and SNP markers. BMC Plant Biology. 15:52.

George, M.L.C., E. Regalado, M. Warburton, S. Vasal, and D. Hoisington. 2004. Genetic diversity of maize inbred lines in relation to downy mildew. Euphytica. 135:145-155.

Gupta, P.K., H.S Balyan, P.C. Sharma, and B. Ramesh. 1996. Microsatellites in plants: a new class of molecular markers. Current Science. 70(1):45-54.

Handiwirawan, E. 2015. Keragaman molekuler dalam suatu populasi. Lokakarya Nasional dan Perlindungan Sumber Daya Genetik di Indonesia: Manfaat Ekonomi untuk Mewujudkan Ketahanan Nasional. Pusat Penelitian dan Pengembangan Peternakan, Bogor. http://kalteng.litbang.pertanian.go.id/eng/pdf/ all-pdf/peternakan /fullteks/lokakarya/lgen0615.pdf (Accessed on May 2015).

Haris, N., H. Aswidinoor, N.T. Mathius, dan A. Purwantara. 2003. Kemiripan genetik klon karet (Hevea brasiliensis muell.arg) berdasarkan metode Amplified Fragment Length Polymorphisms (AFLP). Menara Perkebunan. 71(1):1-15.

Hartati, D. 2006. Keragaman genetik sengon (Albazia falcataria L. Fosberg) melalui DNA marker. Pusat Penelitian dan Pengembangan Hutan Tanaman (P3HT). Yogyakarta.
Hoxha, S., Shariflou, P. Sharp. 2004. Evaluation of genetic diversity in Albanian maize using SSR markers. Maydica:97-103

Juhriah., Masniawati, Baharuddin, Y. Musa, dan M.B. Pabendon. 2012. Deteksi gen phytoene shynthase 1 (psy1) dan karoten plasma nutfah jagung Lokal Sulawesi Selatan untuk seleksi jagung khusus provitamin A. J. Agrivigor. 11(2):152-160.

Johari, S., Sutopo, E. Kurnianto, dan E. Hasviara. 2008. Polimorfisme protein darah ayam kedu. J.Indon.Tro. Anim. Agric. 33(4):313-318.

Khan, I.A., F.S. Awan, A. Ahmad and A.A. Khan. 2004. A modified mini-prep method for economical and rapid extraction of genomic DNA in plants. Plant Mol. Biol. Rep. 22:89a$89 \mathrm{e}$.

Liu, K., M.M Goodman, S. Muse, J.S.C. Smith, E.S. Buckler, J. Doeble. 2003. Genetic structure and diversity among maize inbred lines as inferred from DNA microsatellites. Genetics. 165:2117-2128.

Molin, D., C.J. Coelho, D.S. Maximo, F.S. Ferreira, J.R. Gardingo, and R.R. Matiello. 2013. Genetic diversity in the germplasm of tropical maize landraces determined using molecular markers. Genetics and Molecular Research. 12(1):99-114.

Muis, A., N. Nonci, and M.B. Pabendon. Genetic diversity of S3 maize genotypes resistant to downy mildew based on SSR markers. 2015. Indonesian Journal of Science. 16(2):19-86.

Nurtjahjaningsih, I.L.G., M. Qiptiyah, T. Pamungkas, AYPBC. Widyatmoko, A. Rimbawanto. 2014. Karakterisasi keragaman genetik populasi jabon putih menggunakan penanda Random Amplified Polymorphism DNA. Jurnal Pemuliaan Tanaman Hutan. 2(2):81-92.

Paterniani, E., L.L. Nass, and M.X. Santos. 2000. Ovalor dos recursos geneticos de milho para o Brasil: uma abordagem historica da utilizacao do germoplasma. In: Udry CW and Duarte W (eds) Uma historia Brasileria do Milho: o Valor dos Recursos Geneticos. Paralelo 15. Brasilia. pp11-43.

Pabendon, M.B., M.J. Mejaya, J. Koswara, dan Aswidinnoor H. 2007. Analisis keragaman genetik inbrida jagung berdasarkan marka ssr dan korelasinya dengan data fenotipik fl hasil silang uji. Jurnal Penelitian Pertanian Tanaman Pangan. 26(2):69-77.

Prasanna, B.M. 2010. Phenotypic and moleculer diversity of maize landraces: characterization and utilization. Indian J.Genet. 70(4):315327. 
Rahmawati, B. dan E. Mahajoeno. 2009. Variasi morfologi, isoenzim dan kandungan vitamin $\mathrm{C}$ pada varietas buah naga. Open Acces Nusantara Bioscience. 1:131-137.

Reid, L.M., K. Xiang, X. Zhu, B.R. Baum, and S.J. Mohar. 2011. Genetic diversity analysis of 119 Canadian maize inbred lines based on pedigree and simple sequence repeat markers. J.Plant Sci. 91:651-661.

Rohlf, F.J. 2000. NTSYSpc Numerical taxonomy and multivariate analysis system version 2.1. Applied Biostatistics Inc.

Samanthi, K.W. and B.M. Prasanna. 2012. Microsatellite marker-based diversity and population genetic analysis of selected lowland and mid-altitude maize landrace accessions of India. J.Plant Biocherm. Biotechnol. ISSN 0971-7811.

Senior, M.L., J.P. Murhphy, M.M. Goodman and C.W. Stuber. 1998. Utility of SSRs for determining genetic similarities and relationships in maize using an agarose gel system. Published in Crop Sci. 38:1088-1098.

Smith, J.S.C., E.C.L. Liu, H. Shu, O.S. Smith, S.J. Wall, M.L. Senior, S.E. Mitchell, S. Kresovich, and J. Zeigle. 1997. An evaluation of the utility of SSR loci as molecular markers in maize (Zea mays L.): Comparison with data from RFLPs and pedigree. Theoretical and Applied Genetics. 95:163-173.

Suarni, dan Muh. Yasin. 2011. Jagung sebagai sumber pangan fungsional. Iptek Tanaman Pangan. 6(1):41-56.

Syam, R., G.R. Sadimantara, dan Muzuni. 2012. Analisis variasi genetik jambu mete (Anacardium occidentale 1.) asal Sulawesi
Teggara menggunakan marka molekuler AFLP(Amplified Fragment Length Polimorfism). Agronomi PPsUNHALU. 1(2):164-173.

Terra, T.F., P. Wietholter, C.C. Almeida, S.D.A Silva. 2011. Genetic variability in maize and teosinte populations estimated by microsatellites markers. Ciencia Rural. 41:205-211.

Tasma, I.M., A. Warsun, D. Satyawan, Syafruddin, dan B. Martono. 2013. Analisis kekerabatan 50 aksesi kelapa sawit (Alaeis guineensis Jacq.) asal Kamerun berdasarkan marka mikrosatelit. Jurnal AgroBiogen. 9(1):19-27.

Utami, S.T., D.F. Kusharyati, dan H. Pramono. 2013. Pemeriksaan bakteri Leptospira pada sampel darah manusia suspect lemptospirosis menggunakan metode PCR (Polymerase Chain Reaction). Balaba. 9(2): 74-81.

Vigouroux, Y., J.S. Jaqueth, Y. Matsuoka, O.S. Smith, W.D. Beavis, J.S.C. Smith, and J. Doebley. 2002. Rate and pattern of mutation at microsatellite loci in maize. Mol. Biol. Evol. 19(8):1251-1260.

Vika, T.O., A. Purwantoro, dan R.A. Wulandari. 2015. Keragaman molekuler pada tanaman lili hujan (Zephyranthes spp.). Vegetalika. 4(2):70-77.

Wati, S.I., E. Yuniastuti, dan Nandariyah. 2014. Analisis keragaman pola pita DNA antar varietas gayong (Canna edulis ker.) dari daerah Karanganyar, Solo dan Boyolali berdasarkan penanda RAPD. El-Vivo. 2(1): 90-101. 